\title{
Late Pleistocene and Holocene Mustela remains (Carnivora, Mustelidae) from Bliznets Cave in the Russian Far East
}

\author{
Gennady F. Baryshnikov* \& Ernestina V. Alekseeva
}

\begin{abstract}
Fossil remains of the representatives of genus Mustela from Upper Pleistocene and Holocene levels in Bliznets Cave, located near Nakhodka City, are found to belong to five species: M. erminea, $M$. sibirica, M. eversmanii, $M$. altaica, and $M$. nivalis. Mandibles of $M$. sibirica may be segregated from those of $M$. eversmanii on the basis of position of the incision on angular process. All species, except $M$. eversmanii, currently occur in the southern part of the Russian Far East, while the distribution range of the steppe polecat is shifted to $400-500 \mathrm{~km}$ westwards.

How to cite this article: Baryshnikov G.F., Alekseeva E.V. 2017. Late Pleistocene and Holocene Mustela remains (Carnivora, Mustelidae) from Bliznets Cave in the Russian Far East // Russian J. Theriol. Vol.16. No.1. P.1-14. doi: 10.15298/rusjtheriol.16.1.01
\end{abstract}

KEY WORDS: Mustela, Pleistocene, Holocene, Russian Far East.

Gennady F. Baryshnikov [ursus@zin.ru], Ernestina V. Alekseeva [ernestinaa@list.ru], Zoological Institute of the Russian Academy of Sciences, Universitetskaya Emb. 1, Saint Petersburg 199034, Russia.

\section{Позднеплейстоценовые остатки мустелид рода Mustela (Carnivora, Mustelidae) из пещеры Близнец на Дальнем Востоке России}

\section{Г.Ф. Барышников, Э.В. Алексеева}

\begin{abstract}
РЕЗЮМЕ. Ископаемые остатки представителей рода Mustela из верхнеплейстоценового и голоценового уровней в пещере Близнец, расположенной около города Находка, принадлежат пяти видам: M. erminea, M. sibirica, M. eversmanii, $M$. altaica and M. nivalis. Нижние челюсти M. sibirica и $M$. eversmanii разделены по расположению вырезки углового отростка. Все виды, кроме M. eversmanii, встречаются на юге Дальнего Востока России в настоящее время, в то время как ареал степного хоря сместился к западу на 400-500 км.
\end{abstract}

КЛЮЧЕВЫЕ СЛОВА: Mustela, плейстоцен, голоцен, российский Дальний Восток.

\section{Introduction}

The extant fauna of southern regions of the Russian Far East reveals a high taxonomical and zoogeographical diversity (Kurentsov, 1959, 1965). This is determined by the southern position of the region, nearness of the Pacific Ocean, mosaic distribution of vegetation zones, and meridional extension of the mountain ranges. These factors contribute to a deep interpenetration and mixture of northern and southern species. It is particularly interesting to elucidate the evolutionary history of this fauna, especially at the Pleistocene stage of this process, by studying fossil material.

Smaller carnivores of the genus Mustela L., 1758 (polecats and weasels) are currently represented in the southern regions of Russian Far East (Primorskii Territory) by four species: M. erminea L., 1758, M. sibirica Pallas, 1773, M. altaica Pallas, 1811, and M. nivalis L., 1766 (Yudin, 1984). A vast accumulation of fossil bones and teeth within Upper Pleistocene deposits of Geographical Society Cave (Primorskii Territory, $s$.

* Corresponding author
Primorskii Krai) revealed no remains of these species (Baryshnikov, 2015). These were also not found at the Quaternary localities of Yakutia (Boeskorov \& Baryshnikov, 2013); as a result, the Pleistocene history of these smaller carnivores remains unclear in the region as well as in whole Eastern Siberia. Holocene findings of Mustela species were recorded in the southern part of Primorskii Territory (Ovodov, 1977; Gasilin, 2013; Gasilin et al., 2013).

This is why the material collected by E.V. Alekseeva (excavations of 1973-1980) in Bliznets Cave in Primorskii Territory is of the special value. This scrupulous work yielded the collections of shells of terrestrial mollusks, and abundant bone fragments of birds, bats, rodents, carnivores, and several species of ungulates (Alekseeva \& Golenishchev, 1986; Alekseeva \& Tiunov, 1987; Panteleev \& Alekseeva, 1993; Prozorova \& Alekseeva, 1999). Several species of small-sized mustelids, which were found there, have been tentatively referred by Alekseeva (2003) to Martes zibellina L., 1758, Mustela sibirica, M. eversmanii, M. erminea, and M. nivalis. The focus of present communication is to provide first taxonomic characteristics and to give 


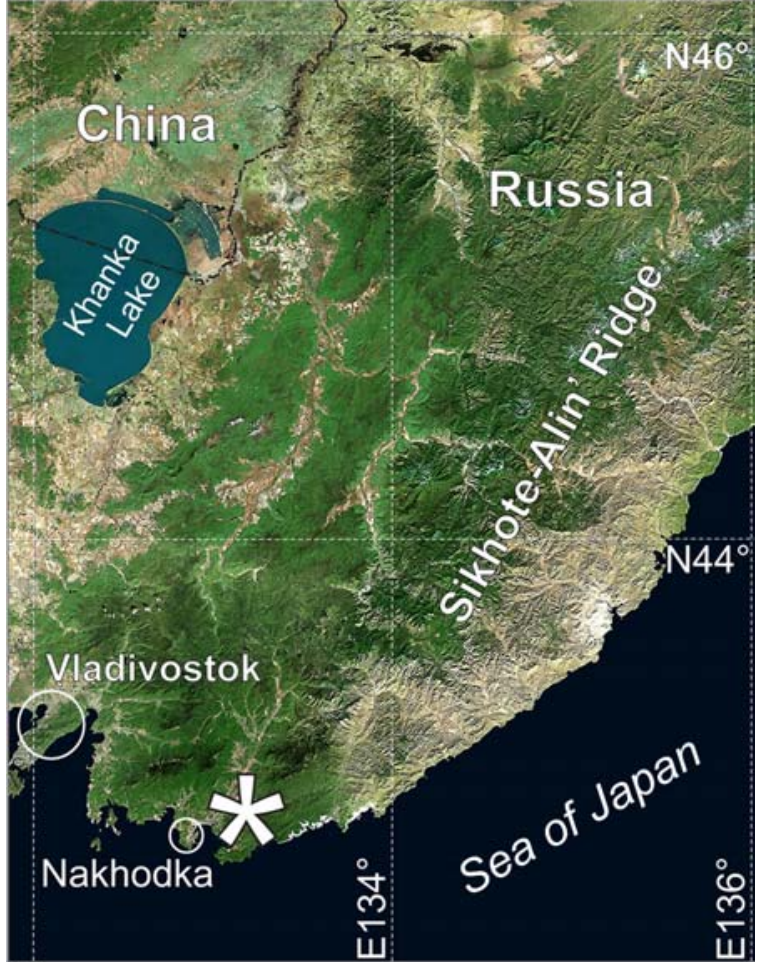

Fig. 1. Location of Bliznets Cave (white star) at Sea of Japan coast.

illustrations of fossil remains representing the genus Mustela in Bliznets Cave. All the examined material is preserved in Zoological Institute, Russian Academy of Sciences in Saint Petersburg (ZIN).

\section{Geographical Situation and Geological Age}

Bliznets Cave represents a vertical karst sinkhole situated on the southern slope of Lozovoi (Chandalaz) Range in South Sikhote Alin (Fig. 1). The cave lies 25 km northwards of Nakhodka City (Primorskii Territory, Russia), at height $300 \mathrm{~m}$ a.s.l. It is confined to a zone of pine-broadleaved forests dominated by oak (Quercus dentata) and lespedeza thickets (Lespedeza bicolor).

Sediment was accumulated through the shaft opening. During the excavations, cave deposits have been exposed in the area of $7 \times 4 \mathrm{~m}$, and at some levels, $7 \times 8$ $\mathrm{m}$. The sedimentary sequence was divided into $10-\mathrm{cm}$ thick horizons. The deepest excavated level is $8.7 \mathrm{~m}$. Two radiocarbon dates have been obtained: $11,060 \pm 110$ (AA-60259) on the basis of goral bone recovered at the depth of $2.9 \mathrm{~m}$ and $12,100 \pm 360$ (AA-60260) on the basis of goral bone found at the depth of $3.0 \mathrm{~m}$. Both dates are referred to the final of Late Pleistocene.

The maximum amount of shells of the hydrophilic mollusk Bradybaena ussuriensis was recorded at the depth of 3.0-2.4 m, which indicates a more humid and, likely, warmer climatic conditions in the south of Primorskii Territory at this stage of sedimentation (Prozorova \& Alekseeva, 1999).

Institutional abbreviations: ISEA - Institute of Systematics and Evolution of Animals, Krakow, Poland; ZIN - Zoological Institute, Russian Academy of Sciences, St. Petersburg, Russia; ZMMU - Zoological Museum, Moscow University, Moscow, Russia.

Dental measurements: $L$ - greatest length, Lbuc buccal length, Llin - lingual length, Ltrd - length of trigonid, $W$ - greatest width

\section{Systematic part}

Family Mustelidae Fischer, 1817

Genus Mustela Linnaeus, 1758

Subgenus Mustela s. 1

Mustela (Mustela) erminea Linnaeus, 1758

The stoat is represented by two right mandibles (Fig. 2, C-F). One mandible (ZIN 37925) was recovered at the depth of $5.2 \mathrm{~m}$, another (ZIN 37922) was found at the depth of $3.1 \mathrm{~m}$, which implies the Late Pleistocene age of both bones. Dimensions of these fossil mandibles resemble those of the recent M. erminea from the Amur River basin (Table 1).

The length of lower carnassial tooth $\mathrm{m} 1$ of the studied specimens (4.7 and $4.8 \mathrm{~mm}$ ) is slightly smaller than the mean value of the length for this tooth $(5.34$ $\mathrm{mm}, 4.4-6.1 \mathrm{~mm}, \mathrm{n}=55)$ in the recent sample from Siberia. Similar tooth size (length of $\mathrm{m} 1$ is $5.1-6.0 \mathrm{~mm}$, $\mathrm{n}=5)$ is characteristic of the Late Pleistocene $M$. erminea from the European localities (Koziarnia, Nietoperzowa and Raj caves in Poland; coll. ISEA). It differs from $M$. nivalis by marked projection of the lingual margin of $\mathrm{ml}$ crown, at the level of protoconid (Rabeder, 1976; Marciszak \& Socha, 2014).

M. erminea now dwells in boreal regions of Eurasia and North America, radiating eastwardly in Eastern Asia up to Northeastern China. In spite of the vast distribution range, this species shows only inconspicuous geographical variation in size and proportions of skull, especially with account of its pronounced sexual and individual variety. It also reveals a very low level of genetic variation (Kurose et al., 2005).

A single fossil finding is known from Altai (Denisova Cave) (Derevianko et al., 2003). Presumably, the Late Pleistocene animals did not markedly differ from the recent ones. Judging from the collection from Bliznets Cave, the fossil stoat from southern part of Primorskii Territory metrically resembled the recent miniature animals of the subspecies $M$. erminea transbaikalica Ognev, 1928 (= naumovi Jurgenson, 1938) occurring in Transbaikalia and in the southern regions of Russian Far East (Aristov \& Baryshnikov, 2001).

The length of $\mathrm{ml}$, similar to that of the examined specimens of $M$. erminea, was reported for $\mathrm{m} 1$ from the left fossil mandible recovered in Locality 3 at Zhouk- 

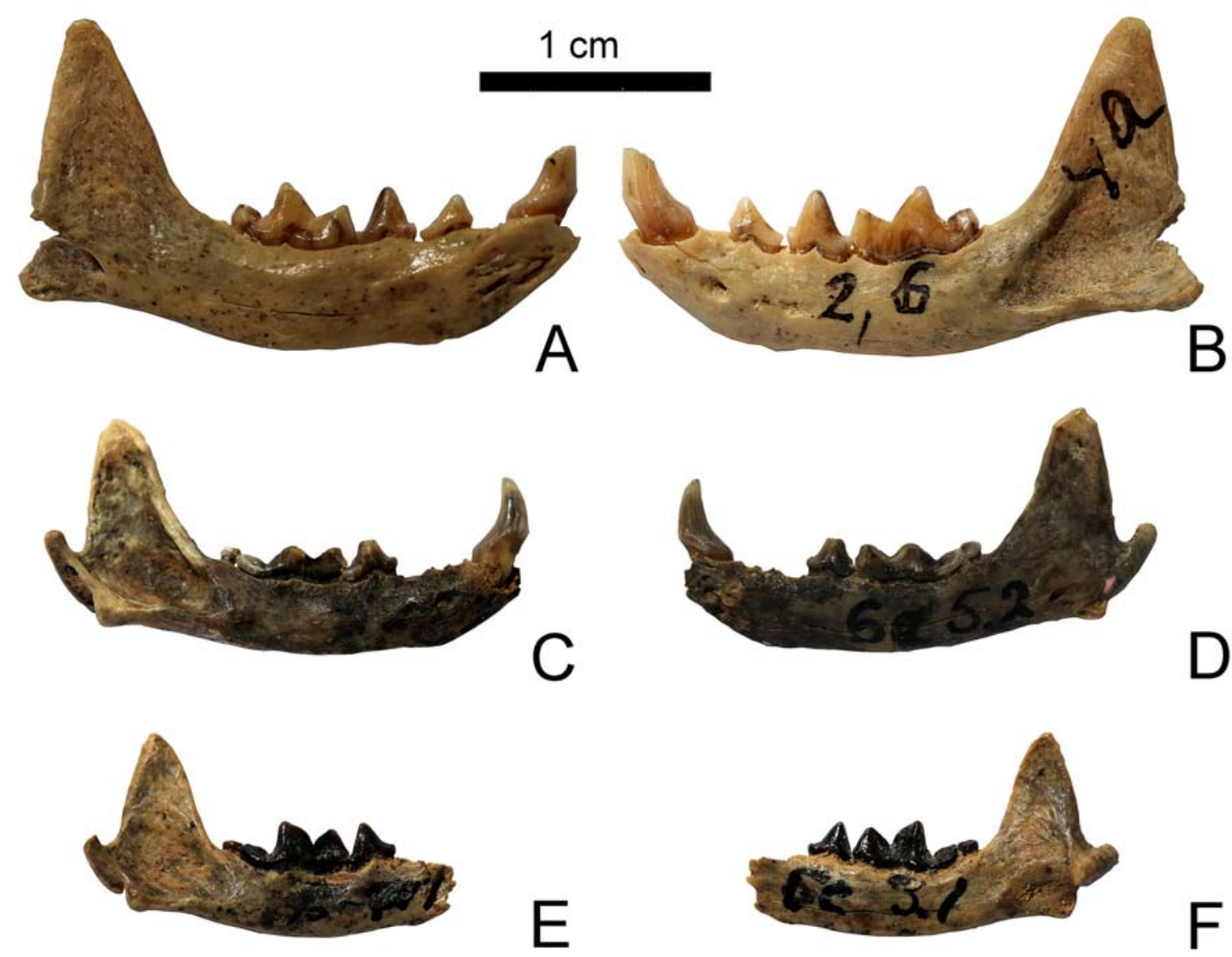

Fig. 2. Mustela altaica (A, B) and M. erminea (C-F), Bliznets Cave, mandibles; buccal (B, C, E) and lingual (A, D, F) views. A, B - ZIN 37923; C, D - ZIN 37925; E, F - ZIN 37922.

oudian in China and regarded as Mustela sp. (Pei, 1936).

Subgenus Kolonokus Satunin, 1911

Mustela (Kolonokus) sibirica Pallas, 1773

A greater portion of the examined material is represented by mustelids resembling $M$. sibirica and $M$. eversmanii by their size. These species are well distinguished by the shape of their skulls; however, their metric characteristics overlap, generating problems in determination of fragmentary material.

Several large cranial fragments recovered at the depth of 5.1-5.3 m are predominantly represented by a rostral portion (Fig. 3). One fragment markedly shows the elongation of postorbital constriction, likewise that
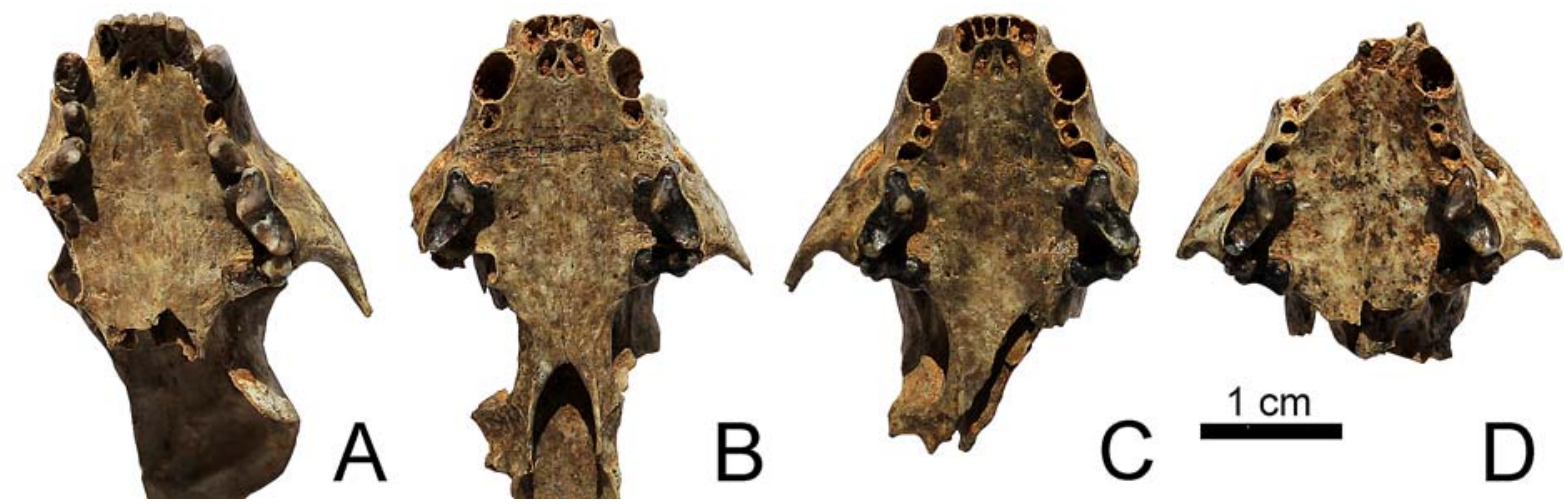

Fig. 3. Mustela sibirica, Bliznets Cave, skull fragments; ventral view. A — ZIN 38049, B — ZIN 37924-3, C - ZIN 379247, D - ZIN 37924-2. 
in $M$. sibirica. The fossil collection also contains four auditory bullae, which are narrow and elongated (fabiform) similar to those of $M$. sibirica. The length of auditory bullae exceeds $16 \mathrm{~mm}$, whereas bullae of the recent subspecies M. eversmanii amurensis Ognev, 1930 surrender $16 \mathrm{~mm}$ in length. The width of each bulla constitutes $55-64 \%$ of its length, which is comparable with this index in $M$. sibirica $(49-63 \%, \mathrm{n}=5)$; meantime, in M. e. amurensis this ratio corresponds to 68 $79 \%(\mathrm{n}=5)$.

The skull rostral portion of $M$. sibirica is more narrow and oblong in comparison with that of $M$. eversmanii. A total size of specimens ZIN 37924-2 and 37924-3 resembles the skull size of $M$. sibirica, though the infraorbital breadth in examined specimens is more pronounced (Table 2). The length of upper carnassial tooth $\mathrm{P} 4$ in the fossil crania constitutes 5.9-6.6 $\mathrm{mm}(\mathrm{n}=4)$.

Segregation of mandibles between $M$. sibirica and $M$. eversmanii was realized on the basis of character discovered by Alekseeva (2003). In M. sibirica, the edge of the incision of angular process lies approximately on the level of posterior margin of coronoid process or in front of it. $M$. eversmanii is characterized by this edge markedly shifted backwards (Fig. 4). This feature provides the possibility for ascribing 11 mandibles to $M$. sibirica (Fig. 5, A-F), whereas 18 mandibles are assigned to $M$. eversmanii (Fig. 6). We failed to attribute another 27 specimens with broken angular processes; these specimens are designated as M. sibirica/eversmanii (Fig. 5, G, H).

$M$. sibirica is represented by 5 left and 6 right mandibles (ZIN 37924-13, 18, 21-23, 31, 35, 44, 4749). These findings were distributed into two levels: having the depth $4.7-5.5 \mathrm{~m}$ and $0.4-1.2 \mathrm{~m}$. The first level is provisionally associated with the Late Pleistocene, whereas the second level is referred to the Holocene age. More robust mandibles are assigned to males and the smaller bones to females (Table 3, 4).

The length of $\mathrm{m} 1$ in the fossil sample of $M$. sibirica constitutes $6.7-7.9 \mathrm{~mm}$ (mean $7.36 \mathrm{~mm}, \mathrm{n}=11$ ), which does not exceed the length limits of the recent $M$. sibirica $(6.2-8.1 \mathrm{~mm}, \mathrm{n}=40)$.

Three measurements $(L, L t r d, W)$ of $\mathrm{m} 1$ preserved in mandibles were used for the Principal Component Analysis. Five samples were analyzed: $M$. sibirica, fossil and recent; $M$. eversmanii, fossil and recent; and subspecies $M$. e. amurensis, recent. Within the spaces of Component 1 (includes all dimensions, 99.5\% of dispersion) and Component 2 (includes tooth width, $0.4 \%$ of dispersion) on the scatter-plot, the specimens of $M$. sibirica and $M$. eversmanii are separated mainly by the Component 1 (Fig. 7), since $M$. eversmanii has larger $\mathrm{m} 1$. No reliable difference has been detected between the fossil and recent samples of $M$. sibirica.

At present, the distribution range of $M$. sibirica cover forest regions of Northern Eurasia from Pechora River basin in the west to Sea of Okhotsk in the east, reaching southwards India and the northern part of

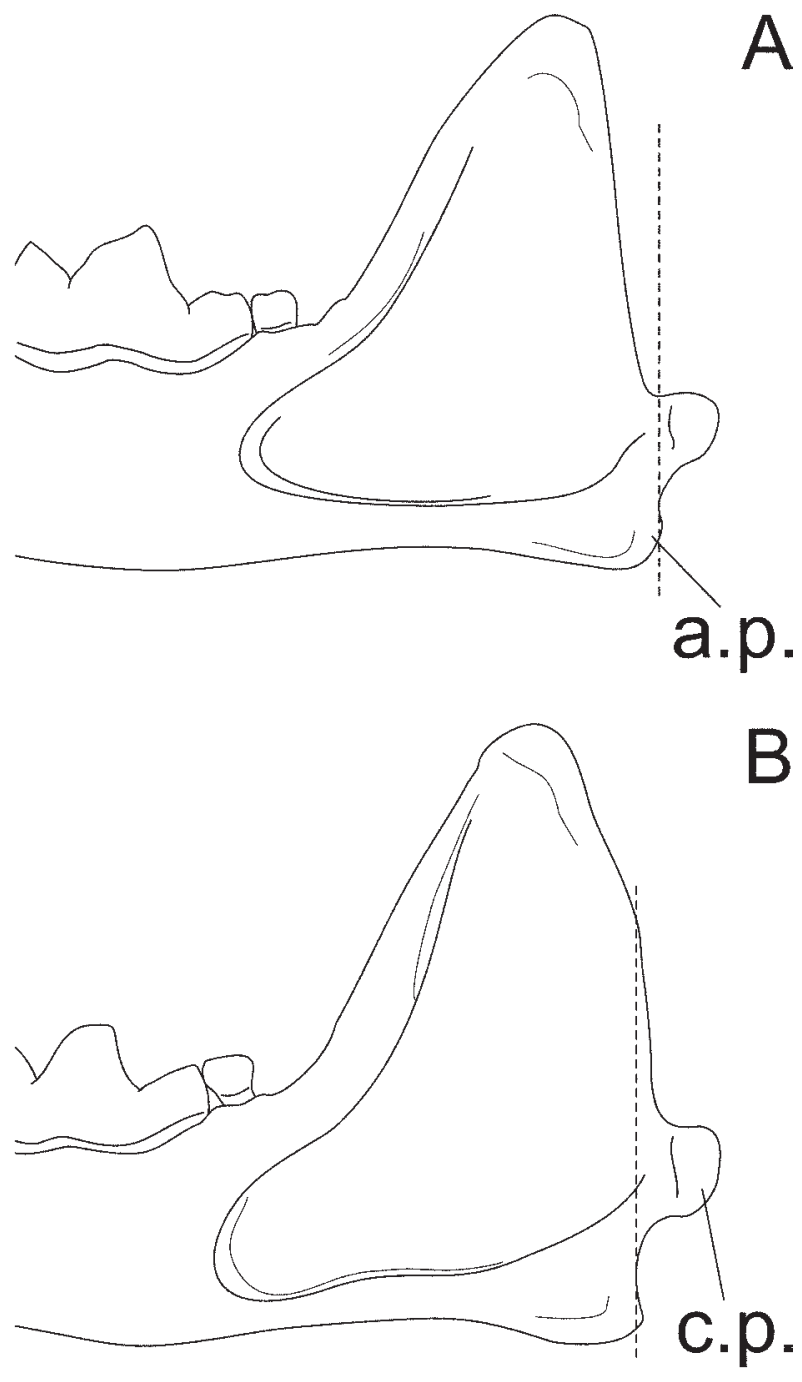

Fig. 4. Difference between mandibles of Mustela eversmanii (A) and M. sibirica (B). Abbreviations: a.p. - angular process, c.p. - condyloid process.

Indo-China. The animals from the southern regions of Russian Far East were referred to the subspecies $M . s$. manchurica Brass, 1911 (Aristov \& Baryshnikov, 2001).

We have no information on Pleistocene findings of fossils belonging to $M$. sibirica in Siberia. The species, most probably, moved northwards only in the postglacial time. This hypothesis is conformed to a striking homogeneity of its craniomandibular characteristics throughout the Siberian part of the distribution range. Holocene findings were reported from Primorskii Territory from Chertovy Vorota, the grotto near Sinie Skaly and from Spasskaya Cave (Kuzmin, 1997; Panasenko, 2010).

$M$. sibirica is also affiliated with the right fossil mandible found in Locality 3 at Zhoukoudian (Pei, 1936). Its $\mathrm{ml}$ (length $8.5 \mathrm{~mm}$ ) is markedly larger in comparison with the specimens from Bliznets Cave. 


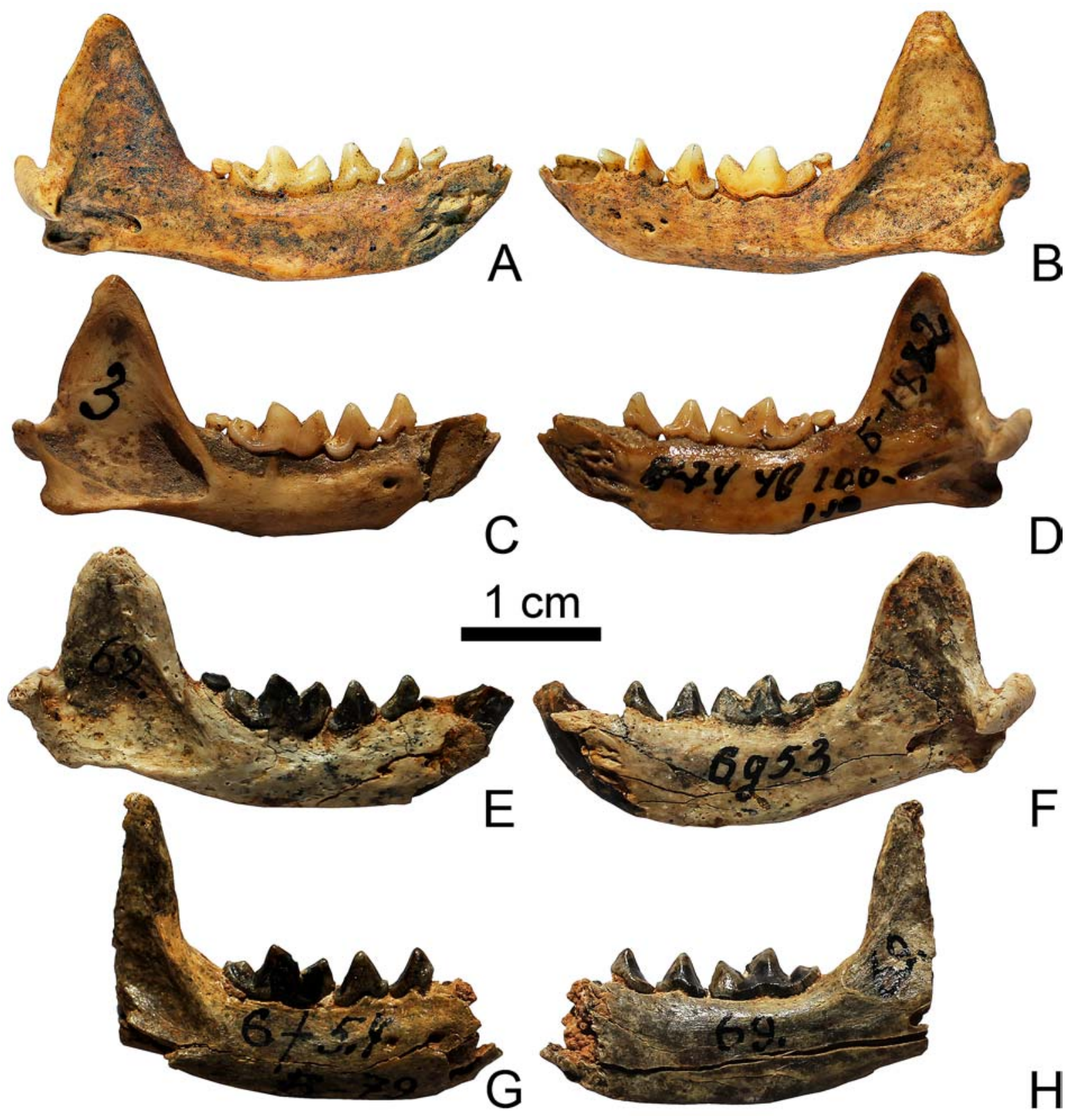

Fig. 5. Mustela sibirica (A-F) and M. sibirica/eversmanii $(\mathrm{G}, \mathrm{H})$, Bliznets Cave, left (A, B) and right (C-H) mandibles; buccal (B, C, E, G) and lingual (A, D, F, H) views. A, B - ZIN 37924-48; C, D - ZIN 37924-18; E, F - ZIN 37924-13; G, H ZIN 37924-8.

Subgenus Putorius G. Cuvier, 1817 Mustela (Putorius) eversmanii Lesson, 1827

Alekseeva (2003) has for the first time recorded a presence of the steppe polecat $(M$. eversmanii) in the former fauna of Primorskii Territory. The nearest place of the species current distribution is known to be in the basin of the middle stream of Amur River (Amurskaya Oblast in Russia and Heilongjiang Province in China) (Aristov \& Baryshnikov, 2001; Smith \& Xie, 2008).
This region is inhabited by comparatively small animals, which were described, on the basis of their skin coloration, as the subspecies M. e. amurensis Ognev (Ognev, 1930). It is regarded to be the most welldefined subspecies of the steppe polecat (Stroganov, 1958). We have examined a series of skulls from Ognev collection (ZMMU S-82905-82909, S-82911, S13175). It was found that their condylobasal length varies from $52.5-56.1 \mathrm{~mm}$ in females $(\mathrm{n}=2)$ to 59.8 $63.7 \mathrm{~mm}(\mathrm{n}=5)$ in males. 

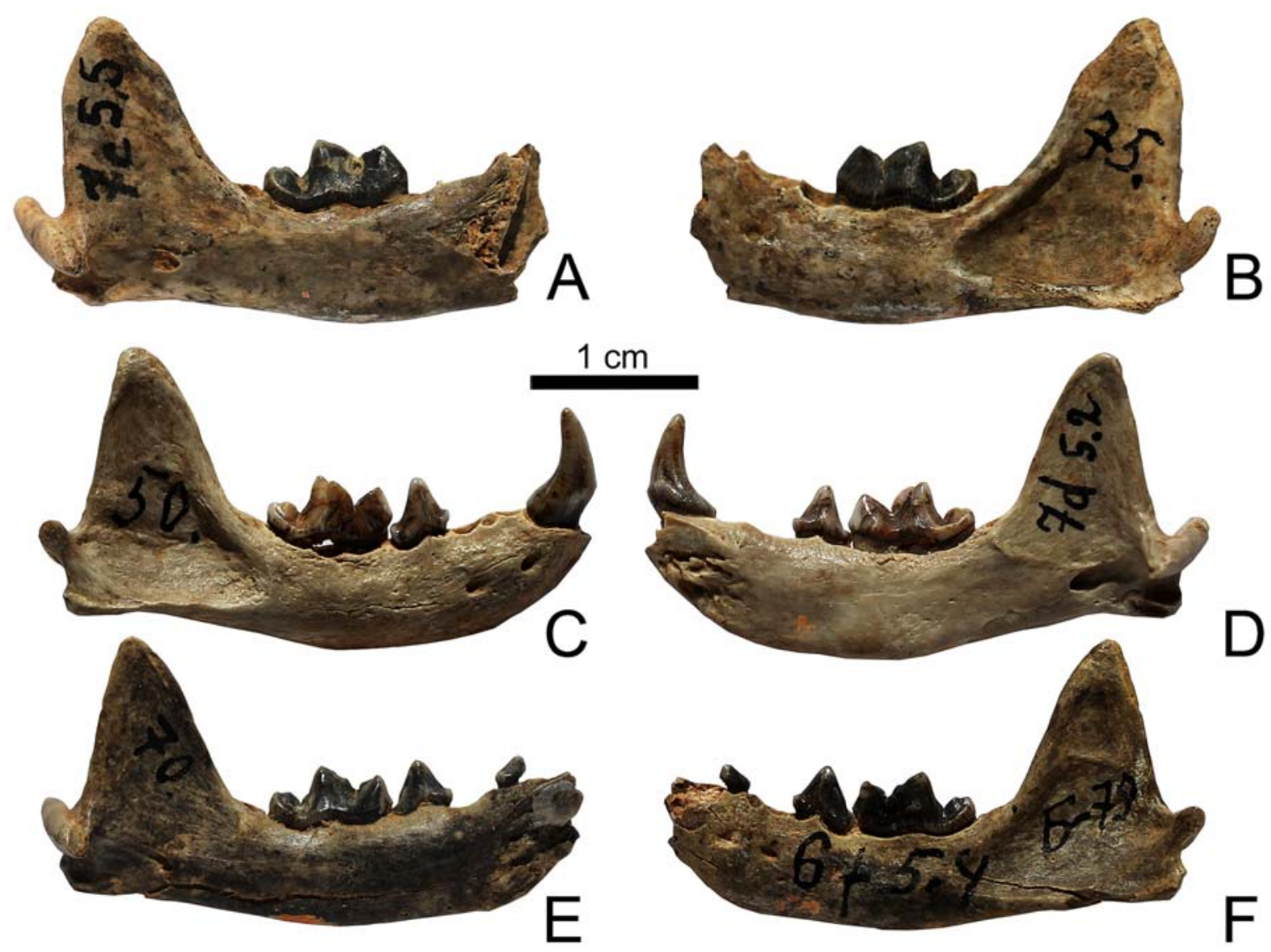

Fig. 6. Mustela eversmanii, Bliznets Cave, left (A, B, E, F) and right (C, D) mandibles; buccal (B, C, F) and lingual (A, D, E) views. A, B - ZIN 37928-7; C, D - ZIN 37928-30; E, F - ZIN 37928-11.

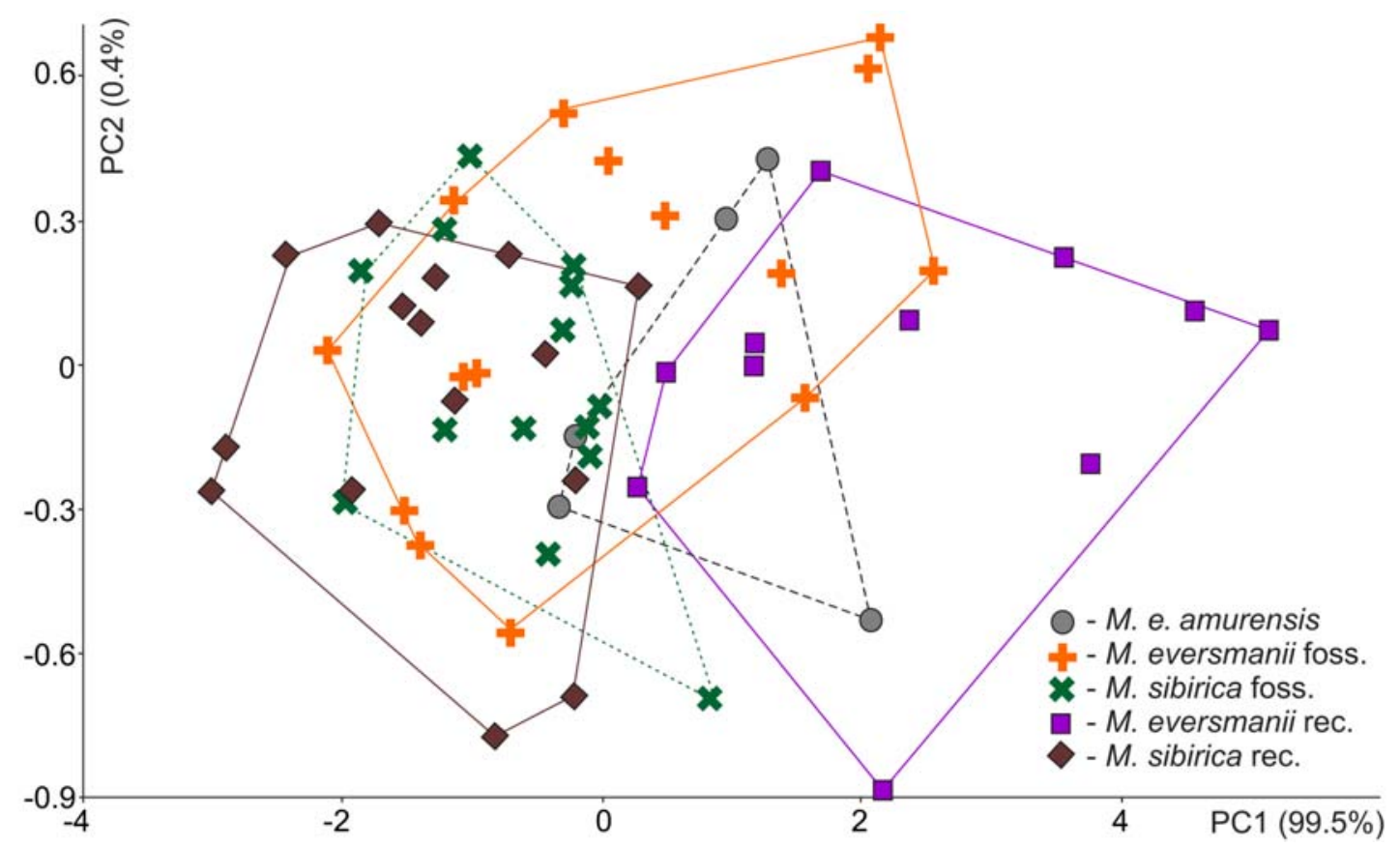

Fig. 7. Principal component analysis of Mustela sibirica (fossil and recent), M. eversmanni (fossil and recent) and recent $M$. e. amurensis. 
Our analysis shows that the fossil material from Bliznets Cave contains 3 cranial fragments as well as 12 left and 6 right mandibles (Fig. 6) belonging to $M$. eversmanii (Tabs 5-8). These bones were excavated from the depth of 4.0-5.5 m, i.e. may be referred to the Late Pleistocene.

The length of upper carnassial tooth varies within the sample from $6.7 \mathrm{~mm}$ to $7.9 \mathrm{~mm}(\mathrm{n}=7)$, which corresponds to this length in the recent $M$. e. amurensis $(6.6-7.6 \mathrm{~mm}, \mathrm{n}=4)$. In the fossil sample of $M$. sibirica from Bliznets Cave, the length of $\mathrm{P} 4$ is a little smaller (6.1-7.1 mm, $\mathrm{n}=7$ ).

The length of the lower carnassial tooth $\mathrm{m} 1$ of the fossil M. eversmanii constitutes $6.8-8.7 \mathrm{~mm}(\mathrm{n}=18)$. Marked variability of this length may be explained by mutual presence of males and females in the sample, since polecats are characterized by pronounced sexual dimorphism in size. M. e. amurensis has the length of $\mathrm{m} 1$ measured $7.3 \mathrm{~mm}(\mathrm{n}=2)$ in females and 7.4-8.0 $\mathrm{mm}(\mathrm{n}=5)$ in males.

Principal Component Analysis, which has been performed for five samples on the basis of three measurements of $\mathrm{m} 1$, revealed inconspicuous graphical difference between the fossil and recent samples of $M$. eversmanii, mainly by Component 2 (tooth width) (Fig. 7). Teeth of the fossil M. eversmanii are found to be somewhat narrower in comparison with those of the recent steppe polecat; however, they are more robust and wider than teeth of $M$. sibirica, notwithstanding a noticeable overlapping between two species on the diagram.

The recent $M$. eversmanii dwells in the steppe zone of Eurasia from Central Europe to Malyi Khingan and the coast of Yellow Sea, occurring southwards as far as Tibet and Sichuan (Smith \& Xie, 2008). Central Asia is inhabited by very large polecats belonging to subspecies M. e. larvatus Hodgson, 1849 and M. e. michnoi (Kastschenko, 1910), whereas M. e. amurensis from the Amur region is noticeably smaller. The Amur subspecies is dimensionally similar to the fossil polecat from Bliznets Cave.

The Late Pleistocene fossil remains of a large individual of $M$. eversmanii have been recorded in Denisova Cave, in southern part of Siberia (Derevianko et al., 2003). It also seems to be interesting a finding of mandible in Ostantsevaya Cave, in Sakhalin Island, which was determined as Mustela cf. eversmanii (Kirillova \& Tesakov, 2008). Its lower carnassial tooth is robust ( $9.8 \mathrm{~mm}$ in length). The Holocene records of the steppe polecat are known in Primorskii Territory from Spasskaya Cave (Panasenko, 2010).

The Late Pleistocene $M$. eversmanii has been found in the fauna of Upper Cave of Zhoukoudian in China (length m1 8.3-8.9 mm) (Pei, 1940).

Subgenus Gale Wagner, 1841

Mustela (Gale) altaica Pallas, 1811

The mountain weasel (or solongoi) is recorded in the bone assemblage of the cave for the first time. It is represented by the left mandible (ZIN 37923-1) collected at the depth of $2.6 \mathrm{~m}$ (Fig. 2, A-B). Its location as well as minor fossilization allows its attribution to the latest Pleistocene or to Holocene. The size of ZIN 37923-1 inconspicuously surpasses that of the male mandible in the recent $M$. altaica from Amur River basin (Table 1). The length of fossil $\mathrm{m} 1(5.7 \mathrm{~mm})$ does not exceed the length limits of this tooth in the recent sample (5.0-6.4 mm, mean $5.79 \mathrm{~mm}, \mathrm{n}=18)$.

Nowadays $M$. altaica occurs in mountains of Southern Siberia and Central Asia southwards as far as Himalaya. Its Late Pleistocene records are scant. Its fossils are known in Siberia from Altaic Denisova Cave (Derevianko et al., 2003). Two cranial fragments from Upper Cave of Zhoukoudian in China referred to $M$. cf. altaica (Pei, 1940) display no size difference from the skulls of the recent mountain weasel.

Another finding of solongoi is provisionally identified in the material from Bliznets Cave on the basis of the left mandible of the immature individual (ZIN 379232 ), with the only $\mathrm{m} 1$ being preserved. A type of preservation of the bone substance as well as the depth of the bone deposition $(1.1 \mathrm{~m})$ suggest the Holocene age of the finding. The measurements of ZIN 37923-2 are similar to those of the recent $M$. altaica; the length of $\mathrm{m} 1$ falls, however, into the maximum values of this parameter in the recent sample (Table 1). The buccal side of $\mathrm{ml}$ reveals two slender supplementary roots beneath the protoconid; the same roots are happened to be developed in M. erminea. We designate ZIN 379232 as $M$. cf. altaica.

\section{Mustela (Gale) nivalis Linnaeus, 1766}

The weasel is represented by 10 mandibles ( 6 left and 4 right bones) (Fig. 8). Among them, 8 specimens were found at the depth of 2.8-5.4 m (ZIN 37927-1, 2, 4, ZIN 37929-1, 2, 3a, 4, 5) and revealed the Pleistocene type of preservation of the bone substance. Another two mandibles (ZIN 37927-3, 37929-3b), originating from the upper horizons, are dated by us to Holocene.

Mandible measurements of the Pleistocene specimens are similar to those of the recent weasel from Primorskii Territory and Northeastern China (Table 9). Lingual margin of $\mathrm{m} 1$ displays no projection characteristic of M. erminea (Rabeder, 1976; Marciszak \& Socha, 2014). In one specimen (ZIN 27927-3) this projection is developed.

The length of fossil $\mathrm{m} 1(3.2-3.8 \mathrm{~mm}$, mean 3.53 $\mathrm{mm}, \mathrm{n}=7$ ) corresponds to that in the sample of nominotypical subspecies $M$. nivalis nivalis (3.1-3.8 mm, mean $3.51, \mathrm{n}=17)$. This subspecies is characterized by a wide distribution range extending from the northern part of Scandinavia as far as Japan Islands and Northern China (Abramov \& Baryshnikov, 2000; Smith \& Xie, 2008). Its representatives exhibit striking uniformity in the size and proportions. They, presumably, dispersed over this extensive territory in postglacial time, radiating from few southern refuges, one of them 

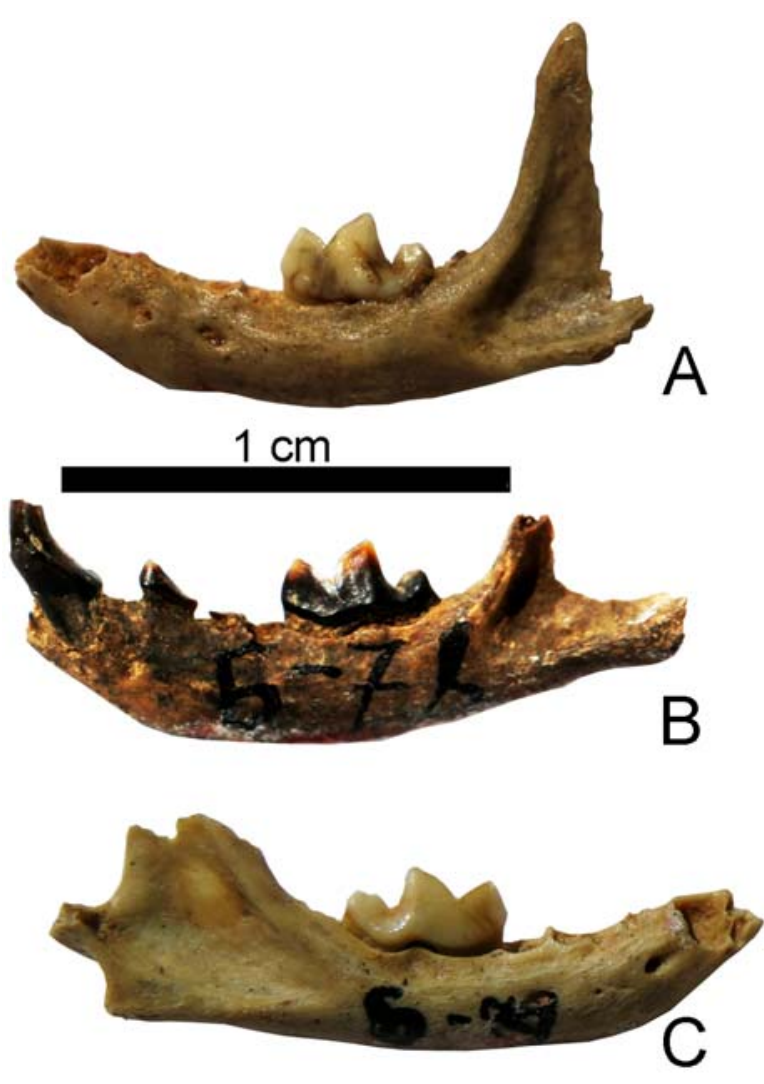

Fig. 8. Mustela nivalis, Bliznets Cave, left (A, B) and right (C) mandibles; buccal view.

A - ZIN 37927-3; B - ZIN 37929-5; C - ZIN 37929-3.

probably had located in the southern part of Russian Far East. This hypothesis is ascertained by the data of phylogeography; molecular phylogenetic analyses show two lineages of $M$. nivalis, one of them extending from the North-Eurasian region to North America (Kurosa et al., 2005).

Fossil findings of $M$. nivalis are recorded in Siberia from the Altai caves: (Denisova Cave, Bukhtarminskaya Cave, Strashnaya Cave) and from karst shafts (Badzheiskaya Lovushka, Syiskaya) (Ovodov, 1980; Derevianko et al., 2003).

The length and width of $\mathrm{m} 1$ of the weasel from Bliznets Cave resemble those of a small mustelid from Middle Pleistocene Locality 1 at Zhoukoudian in China, which was referred to Mustela (or Putorius) sp. (Pei, 1934).

Notably, the dimensions of $M$. nivalis show a slight variability in Eastern Asia, whereas the size of animals from Europe, Mediterranean, and Central Asia is comparatively larger and more pronouncedly variable. In the cold periods of Late Pleistocene, small M. nivalis migrated farther westwards and southwards in comparison with the present time. For example, the length of $\mathrm{m} 1$ varies in the fossil samples from Poland (Mamutova Cave, Koziarnia Cave, coll. ISEA) from 3.0 to $3.7 \mathrm{~mm}$ (mean $3.41 \mathrm{~mm}, \mathrm{n}=13$ ), i.e. corresponds to that of the recent weasel from Siberia.

\section{Conclusions}

The study revealed the presence of five species belonging to Mustela within the fossil collections from Bliznets Cave. These species currently occur in Primorskii Territory, with the exception of the steppe polecat (M. eversmanii) whose recent distribution range is shifted 500-600 km westwards, far inland (Gasilin, 2013). The position of the fossil material in the geological section provided a possibility to establish two stratigraphical species units. The early unit, correlated with the Late Pleistocene, includes four species: M. erminea, M. sibirica, M. eversmanii, and M. nivalis. The second, younger, unit of the Holocene age embraces three species: $M$. sibirica, M. altaica, and $M$. nivalis. The first unit is characteristic by the presence of $M$. eversmanii, which is currently confined to arid steppe localities. The second unit does not include the steppe polecat, and includes the dwellers of mountain and plain forests and riverside thickets (M. sibirica, $M$. altaica).

Presumably, migration of the steppe polecat to the southern regions of Primorskii Territory took place during the Last Glacial Maximum (LGM), in the Late Pleistocene (ca. $19 \mathrm{ka}$ ) or immediately after it. This cold epoch was accompanied with the ocean level lowering, aridization of climate, and expansion of open landscapes. At that time the polecat could migrate onto Sakhalin through a land bridge. At the beginning of Holocene, the rainfall increased and the area of open landscapes were reduced. Probably, their relict remains are represented now by humid herbaceous associations in lowlands around Khanka Lake. Kurentsov (1959) considered the Khanka Plain as a Sungari-Khanka zoogeographical province, into which species of DaurianMongolian steppe fauna could come. This region is still inhabited by such xerophytic rodents as Tscherskia triton (De Winton, 1899), Cricetulus barabensis (Pallas, 1773), and Myospalax psilurus Milne-Edwards, 1874, and birds Perdix daurica (Pallas, 1811) and Glareola pratincola (Linnaeus, 1766). Notably, the Daurian partridge (Perdix daurica) had been more widespread in the Late Pleistocene, reaching the Pacific coast: its fossil remains were recorded in Bliznets Cave (Panteleev \& Alekseeva, 1993).

Thus our study revealed changes in the distribution of smaller mustelids in the southern part of Primorskii Territory, which were caused by climatic and landscape changes at the end of Late Pleistocene.

\section{Acknowledgments}

We are grateful to all participants of the excavations in Bliznets Cave. The material for the comparison has been kindly provided by Dr. S. Kruskop (ZMMU) and Prof. A. Nadachowski (ISEA). We thank Dr. Ya. Kuzmin (Novosibirsk) for his organization of radiocarbon dating. During the work with the MS we were assisted by Dr. L. Voita, Dr. S. Baryshnikova and Julia Shemyakina (ZIN). The study was fulfilled within a framework of 
the Federal theme of the Theriology lab. of ZIN RAS no. ÀÀÀÀ-À17-117022810195-3 "Phylogeny, morphology and systematics of placental mammals", and was financially supported by the Russian Foundation for Basic Research, project no. 13-04-00081-a.

\section{References}

Abramov A.V., Baryshnikov G.F. 2000. Geographic variation and intraspecific taxonomy of weasel Mustela nivalis (Carnivora, Mustelidae) // Zoosystematica Rossica. Vol.8 (for 1999). No.2. P.365-402.

Alekseeva E.V. 2003. [Bones of small Mustelidae in Bliznets Cave-well, South Sikhote Alin] // Teriofauna Rossii i sopretel'nykh territorii. VII s'ezd Teriologicheskogo obschestva. Moscow. P.16. [in Russian].

Alekseeva E.V. \& Golenishchev F.N. 1986. [Fossil remains of voles of genus Microtus from southern Primorye (Bliznets Cave)] // Trudy Zoologicheskogo Instituta AN SSSR. Vol.156. P.134-142 [in Russian].

Alekseeva E.V. \& Tiunov M.P. 1987. [Variability of bat species (Chiroptera, Rhinolophidae, Vespertilionidae) in final Pleistocene of south Primorye] // Voprosy evolutsii, zoologii i genetiki mlekopitayushchikh. Vladivostok. P.107-110 [in Russian].

Aristov A.A. \& Baryshnikov G.F. 2001. [The mammals of Russia and adjacent territories. Carnivores and pinnipeds]. Saint-Petersburg: Zoological Institute Press. 560 p. [in Russian].

Baryshnikov G. 2015. Late Pleistocene Ursidae and Mustelidae remains (Mammalia, Carnivora) from Geographical Society Cave in the Russian Far East // Proceedings of the Zoological Institute RAS. Vol.319. No.1. P.3-22.

Boeskorov G.G. \& Baryshnikov G.F. 2013. [Late Quaternary Carnivora of Yakutia]. Saint-Petersburg: Nauka. 199 p. [in Russian].

Derevianko A.P., Shunkov M.V., Agadjanian A.K., Baryshnikov G.F., Malaeva E.M., Ulianov V.A., Kulik N.A., Postnov A.V. \& Anoikin A.A. 2003. [Paleoenvironment and Paleolithic human occupation of Gorny Altai. Subsistence and adaptation in the vicinity of Denisova Cave]. Novosibirsk: Institute of Archaeology and Ethnography SB RAS Press. 448 p. [in Russian, with English summary].

Gasilin V.V. 2013. [Large mammals of Primorie in Holocene] // Zoologicheskii Zhurnal. Vol.92. No.9. P.10551063 [in Russian, with English summary].

Gasilin V.V., Panasenko V.E., Vasilieva L.E. \& Tatarnikov V.A. 2013. [Paleofauna from Tetukhinskaya Cave (Middle Sikhote-Aline Range)] // Askeev I.V. \& Ivanov D.V. (eds.). The Dynamics of Modern Ecosystems in the Holocene: Proceeding Third Russian Scientific Conference with International Participation. Kazan: "Otechestvo" Publishing House. P.127-130 [in Russian].

Kirillova I.V. \& Tesakov A.S. 2008. New mammalian elements of the Ice Age assemblage on the Sakhalin Island // Mammal Study. Vol.33. P.87-92.

Kurentsov A.I. 1959. [The fauna of Amur Region and Primorye Territory]. Khabarovsk: Khabarovsk Press. 263 p. [in Russian].
Kurentsov A.I. 1965. [The zoogeography of the Amur Region]. Moskwa-Leningrad: Nauka. 155 p. [in Russian].

Kurose N., Abramov A.V. \& Masuda R. 2005. Comparative phylogeography between the ermine Mustela erminea and the least weasel M. nivalis of Palaearctic and Nearctic Regions, based on analysis of mitochondrial DNA control region sequences // Zoological Sciences. Vol.22. P.1069-1078.

Kuzmin Ya.V. 1997. Vertebrate animal remains from prehistoric and medieval settlements in Primorye (Russian Far East) // International Journal of Osteoarchaeology. Vol.7. P.172-180.

Marciszak A. \& Socha P. 2014. Stoat Mustela erminea Linnaeus, 1758 and weasel Mustela nivalis Linnaeus, 1766 in palaeoecological analysis: A case study of Biœnik Cave // Quaternary International. Vol.339-340. P.258265.

Ognev S.V. 1930. [New Amur polecat] // Okhotnik. No.1. P.25. [in Russian].

Ovodov N.D. 1977. [Late Quaternary fauna of mammals (Mammalia) of south of Ussiry region] // Yudin B.S. (ed.). Fauna i sistematika pozvonochnykh Sibiri. Novosibirsk: Nauka. P.157-177 [in Russian].

Ovodov N.D. 1980. [Mammalian remains from cave localities of Siberia and Far East] // Karst Dal'nego Vostoka i Sibiri. Vladivostok: Izdatel'stvo DVNC AN SSSR. P.154-163 [in Russian].

Panasenko V.E. 2010. Preliminary resalts of paleobtological investigations in Spasskaya Cave in Primorsky Territory // Speleologiya i spelestologiya: razvitie I vzaimodeisatvie nauk. Naberezhnye Zhelny. P.61-63 [in Russian.]

Panteleev A.V. \& Alekseeva E.V. 1993. [Fossil birds from Bliznets Cave at Sikhote-Alin and landscape-climatic conditions their habitation in Holocene] // Russkii Ornitologicheskii Zhurnal. Vol.2. No.2. P.133-144 [in Russian].

Pei W.C. 1934. On the Carnivora from Locality 1 of Choukoutien // Palaeontologia Sinica. Ser. C. Vol.8. No.1. P.1165.

Pei W.C. 1936. On the mammalian remains from Locality 3 at Choukoutien // Palaeontologia Sinica. Ser. C. Vol.7. No.5. P.1-108.

Pei W.C. 1940. The Upper Cave Fauna of Choukoutien // Palaeontologia Sinica. Ser. C. Vol.10. P.1-84.

Prozorova L.A. \& Alekseeva E.V. 1999. [Fossil molluscs from the cave Bliznets (southern Sikhote-Alin)] // Bulleten Dal'nevostochnogo Malakologicheskogo Obshchestva. Vol.3. P.26-30 [in Russian].

Rabeder G. 1976. Die Carnivore (Mammalia) aus dem Altpleistozän von Deutsch-Altenburg 2. Mit Beiträgen zur Systematik einiger Musteliden und Caniden // Beiträge zur Paläontologie von Österreich. Vol.1. P.5-119.

Stroganov S.U. 1958. [Review of subspecies of steppe polecat (Putorius eversmani Lesson) of the Siberian fauna] // Izvestiya Sibirskogo Otdeleniya Akademii Nauk SSSR. No.11. P.149-155 [in Russian].

Smith A.T. \& Xie Y. 2008. A guild to the mammals of China. Princeron and Oxford: Princeton University Press. 544 p.

Yudin V.G. 1984. [Order Carnivora] // Krivosheev V.G. (ed.). Nasemnye mlekopitayushchie Dal'nego Vostoka SSSR. Moscow: Nauka. P.216-316 [in Russian]. 
Table 1. Measurements (mm) of mandibles of Mustela erminea and M. altaica from the Russian Far East.

\begin{tabular}{|c|c|c|c|c|c|c|}
\hline \multirow{4}{*}{ Measurements } & \multicolumn{3}{|c|}{ M. erminea } & M. cf. altaica & \multicolumn{2}{|c|}{ M. altaica } \\
\hline & \multirow{2}{*}{\multicolumn{2}{|c|}{$\begin{array}{l}\text { Late Pleistocene } \\
\text { Bliznets Cave }\end{array}$}} & \multirow{3}{*}{$\begin{array}{c}\text { Recent } \\
\text { Amur } \\
\text { Region } \\
\text { ZIN } 32100 \\
\text { ad., O }\end{array}$} & \multirow{3}{*}{$\begin{array}{c}\text { Holocene } \\
\text { Bliznets Cave } \\
\begin{array}{c}\text { ZIN } 37923 \\
\text { sad. }\end{array} \\
\end{array}$} & \multirow{3}{*}{$\begin{array}{c}\text { Late } \\
\text { Pleistocene } \\
\begin{array}{c}\text { Bliznets } \\
\text { Cave }\end{array} \\
\text { ZIN } 37923\end{array}$} & \multirow{3}{*}{$\begin{array}{c}\text { Recent } \\
\begin{array}{c}\text { Amur } \\
\text { Region }\end{array} \\
\text { ZIN 14508 } \\
\sigma^{T}\end{array}$} \\
\hline & & & & & & \\
\hline & ZIN 37925 & $\begin{array}{c}\text { ZIN } \\
37922\end{array}$ & & & & \\
\hline Lc1-m2 & 12.7 & & 13.7 & 18.2 & 16.0 & 14.4 \\
\hline Lp4-m2 & 7.7 & 7.4 & 8.2 & 11.6 & 9.4 & 8.9 \\
\hline Height before $\mathrm{m} 1$ & 3.4 & 3.0 & 3.0 & 5.2 & 4.3 & 4.3 \\
\hline $\begin{array}{l}\text { Height of the } \\
\text { vertical ramus }\end{array}$ & 9.4 & 8.1 & 10.0 & 14.5 & 12.8 & 12.5 \\
\hline \multicolumn{7}{|c|}{ Teeth } \\
\hline Lc1 & 2.3 & & 2.8 & & 2.9 & 2.9 \\
\hline Wc1 & 2.0 & & 1.9 & & 2.1 & 1.9 \\
\hline Lp4 & 2.4 & 2.1 & 2.5 & & 2.9 & 3.0 \\
\hline Wp4 & 1.3 & 1.0 & 1.4 & & 1.5 & 1.4 \\
\hline $\mathrm{Lm} 1$ & 4.8 & 4.7 & 4.9 & 6.4 & 5.7 & 5.4 \\
\hline Ltrdm1 & 3.5 & 3.4 & 3.6 & 4.5 & 4.1 & 4.0 \\
\hline $\mathrm{Wm} 1$ & 1.7 & 1.6 & 1.8 & 2.1 & 2.1 & 1.8 \\
\hline $\mathrm{Lm} 2$ & 0.9 & 0.9 & 1.1 & & & \\
\hline $\mathrm{Wm} 2$ & 0.9 & 0.7 & 1.0 & & & \\
\hline
\end{tabular}

Table 2. Measurements (mm) of skull fragments of Mustela sibirica from the Russian Far East.

\begin{tabular}{|c|c|c|c|c|c|}
\hline \multirow{3}{*}{ Measurements } & \multicolumn{4}{|c|}{ Late Pleistocene } & \multirow{3}{*}{$\begin{array}{c}\text { M.s. } \\
\begin{array}{c}\text { manchurica, } \\
\text { recent }\end{array} \\
\text { Amur Region } \\
\text { ZIN 9743, } \sigma^{7}\end{array}$} \\
\hline & \multicolumn{4}{|c|}{ Bliznets Cave } & \\
\hline & ZIN 37924-2 & ZIN 37924-3 & ZIN 38049 & ZIN 37924-7 & \\
\hline Medial palatal length & & 24.4 & & & 28.0 \\
\hline LC1-M1 & 16.7 & 16.5 & 17.2 & 16.5 & 17.8 \\
\hline LC1-P4 & 15.1 & 15.2 & 12.0 & 11.7 & 16.2 \\
\hline LP3-M1 & 11.9 & & & & 12.2 \\
\hline $\begin{array}{l}\text { Least breadth between the } \\
\text { orbits }\end{array}$ & 12.9 & 12.6 & 13.4 & 13.3 & 11.9 \\
\hline Greatest palatal breadth & 19.1 & 19.2 & & 19.1 & 20.7 \\
\hline Breadth at the canine alveoli & & ca13.0 & 13.0 & 12.9 & 13.4 \\
\hline \multicolumn{6}{|c|}{ Teeth } \\
\hline $\mathrm{LC} 1$ & & & 3.1 & & 3.6 \\
\hline WC1 & & & 2.4 & & 3.1 \\
\hline LP3 & & & 3.6 & & 4.3 \\
\hline WP3 & & & 1.8 & & 2.0 \\
\hline LP4 & 6.4 & 5.9 & 6.6 & 6.6 & 7.0 \\
\hline WP4 & 3.5 & 3.3 & 3.6 & 3.5 & 3.4 \\
\hline LlinM1 & 2.5 & 2.3 & 2.7 & 2.6 & 2.6 \\
\hline LbucM1 & 2.7 & 2.6 & 2.6 & 2.7 & 3.2 \\
\hline WM1 & 5.1 & 5.0 & 5.3 & 5.0 & 5.1 \\
\hline
\end{tabular}


Table 3. Measurements (mm) of male mandibles of Mustela sibirica from the Russian Far East.

\begin{tabular}{|c|c|c|c|c|c|c|}
\hline \multirow{3}{*}{ Measurements } & \multicolumn{3}{|c|}{ Late Pleistocene } & \multicolumn{2}{|c|}{ Holocene } & \multirow{2}{*}{$\begin{array}{c}\text { M. s. manchurica, } \\
\text { recent } \\
\text { Amur Region } \\
\end{array}$} \\
\hline & \multicolumn{5}{|c|}{ Bliznets Cave } & \\
\hline & $\begin{array}{c}\text { ZIN } \\
37928-13\end{array}$ & $\begin{array}{c}\text { ZIN } \\
37928-47\end{array}$ & $\begin{array}{c}\text { ZIN } \\
37928-49\end{array}$ & $\begin{array}{c}\text { ZIN } \\
37924-18\end{array}$ & $\begin{array}{c}\text { ZIN } \\
37928-48\end{array}$ & ZIN $92780^{7}$ \\
\hline Total length & & & & 33.3 & 35.7 & 36.7 \\
\hline Lc1-m2 & 21.2 & & 20.5 & 20.7 & 20.4 & 21.1 \\
\hline Lp4-m2 & 12.6 & & 12.1 & 12.7 & 11.6 & 13.4 \\
\hline $\begin{array}{l}\text { Height before } \\
\mathrm{m} 1\end{array}$ & 6.6 & 6.4 & 6.8 & 6.0 & 6.3 & 6.3 \\
\hline $\begin{array}{l}\text { Height of the } \\
\text { vertical ramus }\end{array}$ & 16.5 & 17.2 & 14.8 & 17.5 & 18.2 & 18.3 \\
\hline \multicolumn{7}{|c|}{ Teeth } \\
\hline Lc1 & & & 3.1 & & & 4.0 \\
\hline Wc1 & & & 2.7 & & & 2.8 \\
\hline Lp2 & & & & & 2.3 & 2.3 \\
\hline Wp2 & & & & & 1.8 & 1.9 \\
\hline Lp3 & 3.0 & & 2.7 & 3.0 & 2.6 & 2.7 \\
\hline Wp3 & 1.9 & & 1.8 & 2.0 & 1.9 & 1.9 \\
\hline Lp4 & 3.4 & & 4.0 & 3.8 & 3.7 & 4.1 \\
\hline Wp4 & 2.2 & & 2.0 & 2.1 & 2.1 & 2.1 \\
\hline Lm1 & 7.9 & 7.5 & 7.3 & 7.6 & 7.4 & 7.9 \\
\hline Ltrdm1 & 5.5 & 5.6 & 5.4 & 5.6 & 5.3 & 5.4 \\
\hline $\mathrm{Wm} 1$ & 3.2 & 2.8 & 2.6 & 2.7 & 2.9 & 2.8 \\
\hline Lm2 & 2.5 & 1.9 & & 1.6 & & 1.9 \\
\hline $\mathrm{Wm} 2$ & 1.9 & 1.7 & & 1.7 & & 1.7 \\
\hline
\end{tabular}

Table 4. Measurements (mm) of female mandibles of Mustela sibirica from the Russian Far East.

\begin{tabular}{|c|c|c|c|c|}
\hline \multirow{3}{*}{ Measurements } & \multicolumn{3}{|c|}{ Late Pleistocene } & $\begin{array}{l}\text { M. s. manchurica, } \\
\text { recent }\end{array}$ \\
\hline & \multicolumn{3}{|c|}{ Bliznets Cave } & Amur Region \\
\hline & ZIN 37924-31 & ZIN 37924-34 & ZIN 37924-44 & ZIN 32081 ㅇ \\
\hline Total length & 30.5 & 32.0 & & 28.5 \\
\hline Lc1-m2 & 18.9 & 19.5 & & 17.9 \\
\hline Lp4-m2 & 11.4 & 11.4 & 12.2 & 10.3 \\
\hline Height before $\mathrm{m} 1$ & 5.7 & 5.8 & 6.5 & 4.1 \\
\hline Height of the vertical ramus & 15.3 & 14.9 & 15.3 & 13.3 \\
\hline \multicolumn{5}{|c|}{ Teeth } \\
\hline Lc1 & & 3.8 & & 3.2 \\
\hline $\mathrm{Wc1}$ & & 2.7 & & 2.4 \\
\hline Lp2 & 2.2 & 2.0 & & 2.0 \\
\hline Wp2 & 1.6 & 1.4 & & 1.3 \\
\hline Lp3 & & 2.6 & 2.7 & 2.5 \\
\hline Wp3 & & 1.7 & 1.9 & 1.5 \\
\hline Lp4 & 3.6 & 3.3 & 3.7 & 3.4 \\
\hline Wp4 & 1.9 & 1.8 & 1.8 & 1.8 \\
\hline Lm1 & 7.1 & 6.7 & 7.2 & 6.5 \\
\hline Ltrdm1 & 5.2 & 5.0 & 5.3 & 4.8 \\
\hline Wm1 & 2.7 & 2.6 & 2.6 & 2.4 \\
\hline $\mathrm{Lm} 2$ & & & & 1.3 \\
\hline $\mathrm{Wm} 2$ & & & & 1.5 \\
\hline
\end{tabular}


Table 5. Measurements (mm) of male skull fragments of Mustela eversmanii from the Russian Far East.

\begin{tabular}{|c|c|c|c|c|c|}
\hline \multirow{3}{*}{ Measurements } & \multicolumn{3}{|c|}{ Late Pleistocene } & \multicolumn{2}{|c|}{ M. e. amurensis, recent } \\
\hline & \multicolumn{3}{|c|}{ Bliznets Cave } & \multicolumn{2}{|c|}{ Amur Region } \\
\hline & ZIN 37928-4 & ZIN 37928-5 & ZIN 37928-6 & $\begin{array}{c}\text { ZMMU S- } \\
13175\end{array}$ & $\begin{array}{l}\text { ZMMU S- } \\
82909 \mathrm{O}^{7}\end{array}$ \\
\hline Medial palatal length & & & & 30.0 & 31.9 \\
\hline LC1-M1 & & & ca19.0 & 19.1 & 19.7 \\
\hline LC1-P4 & 19.1 & ca16.8 & ca17.6 & 17.4 & 18.3 \\
\hline LP3-M1 & & & 12.8 & 13.2 & 12.6 \\
\hline Least breadth between the orbits & & & & 16.7 & 15.8 \\
\hline Greatest palatal breadth & & & & 22.1 & 22.9 \\
\hline Breadth at the canine alveoli & & & & 15.6 & 16.4 \\
\hline \multicolumn{6}{|c|}{ Teeth } \\
\hline LC1 & 4.1 & & & 3.6 & 4.0 \\
\hline WC1 & 3.4 & & & 2.9 & 2.7 \\
\hline LP3 & 4.4 & 3.9 & 4.0 & 3.9 & 3.9 \\
\hline WP3 & 2.2 & 2.1 & 2.1 & 2.5 & 2.2 \\
\hline LP4 & 7.8 & 7.0 & 7.5 & 7.5 & 7.6 \\
\hline WP4 & 4.1 & 3.8 & 4.5 & 3.9 & 3.5 \\
\hline LbucM1 & & & 2.7 & 2.8 & 2.4 \\
\hline LlinM1 & & & 3.4 & 2.6 & 2.6 \\
\hline WM1 & & & 6.2 & 5.5 & 5.4 \\
\hline
\end{tabular}

Table 6. Measurements (mm) of male mandibles of Mustela eversmanii from the Russian Far East.

\begin{tabular}{|c|c|c|c|c|c|c|c|}
\hline \multirow{3}{*}{ Measurements } & \multicolumn{6}{|c|}{ Late Pleistocene } & \multirow{3}{*}{$\begin{array}{c}\begin{array}{c}\text { M. e. amurensis, } \\
\text { recent }\end{array} \\
\text { Amur Region } \\
\text { ZMMU S- } \\
13175\end{array}$} \\
\hline & \multicolumn{6}{|c|}{ Bliznets Cave } & \\
\hline & $\begin{array}{c}\text { ZIN } \\
37928-3 \\
\end{array}$ & $\begin{array}{c}\text { ZIN } \\
37928-6 \\
\end{array}$ & $\begin{array}{c}\text { ZIN } \\
37928-7 \\
\end{array}$ & $\begin{array}{c}\text { ZIN } \\
37928-10 \\
\end{array}$ & $\begin{array}{c}\text { ZIN } \\
37928-15 \\
\end{array}$ & $\begin{array}{c}\text { ZIN } \\
37928-15 \mathrm{a} \\
\end{array}$ & \\
\hline Total length & & & & & & & 38.0 \\
\hline Lc1-m2 & & & & $\mathrm{ca} 21.5$ & & 21.1 & 22.7 \\
\hline Lp4-m2 & 14.6 & & ca14.5 & 13.3 & 14.1 & 12.5 & 13.2 \\
\hline $\begin{array}{l}\text { Height before } \\
\mathrm{m} 1\end{array}$ & 7.5 & 7.4 & 6.9 & 6.6 & 8.5 & 6.8 & 7.4 \\
\hline $\begin{array}{l}\text { Height of the } \\
\text { vertical ramus }\end{array}$ & & & 18.1 & & & & 18.6 \\
\hline \multicolumn{8}{|c|}{ Teeth } \\
\hline Lc1 & & & & & & 4.2 & 4.4 \\
\hline $\mathrm{Wc1}$ & & & & & & 2.9 & 2.8 \\
\hline Lp2 & 2.5 & & & & & 2.5 & 2.4 \\
\hline Wp2 & 1.9 & & & & & 1.6 & 1.8 \\
\hline Lp3 & 3.3 & & & 3.5 & & 2.6 & 3.2 \\
\hline Wp3 & 2.2 & & & 2.1 & & 2.1 & 2.3 \\
\hline Lp4 & & & & 4.4 & 4.5 & 4.0 & 4.1 \\
\hline Wp4 & & & & 2.4 & 2.7 & 2.1 & 2.4 \\
\hline Lm1 & 7.6 & 8.0 & 8.7 & 8.0 & 8.6 & 7.8 & 7.9 \\
\hline Ltrdm1 & 5.6 & 6.1 & 6.2 & 6.1 & 6.3 & 5.8 & 6.0 \\
\hline $\mathrm{Wm} 1$ & 2.7 & 3.2 & 3.1 & 3.1 & 3.3 & 2.9 & 3.0 \\
\hline Lm2 & & & & 2.3 & & 1.7 & 1.4 \\
\hline $\mathrm{Wm} 2$ & & & & 1.7 & & 1.4 & 1.6 \\
\hline
\end{tabular}


Table 7. Measurements (mm) of female mandibles of Mustela eversmanii from the Russian Far East.

\begin{tabular}{|c|c|c|c|c|c|c|c|}
\hline \multirow{3}{*}{ Measurements } & \multicolumn{7}{|c|}{ Late Pleistocene } \\
\hline & \multicolumn{7}{|c|}{ Bliznets Cave } \\
\hline & $\begin{array}{c}\text { ZIN } \\
37928-11\end{array}$ & $\begin{array}{c}\text { ZIN } \\
37928-12\end{array}$ & $\begin{array}{c}\text { ZIN } \\
37928-16\end{array}$ & $\begin{array}{c}\text { ZIN } \\
37928-19\end{array}$ & $\begin{array}{c}\text { ZIN } \\
37928-24\end{array}$ & $\begin{array}{c}\text { ZIN } \\
37928-25\end{array}$ & $\begin{array}{c}\text { ZIN } \\
37928-26 \\
\end{array}$ \\
\hline Total length & ca31.0 & & & & 31.0 & & 30.5 \\
\hline Lc1-m2 & 19.6 & & & 19.5 & 19.3 & 19.6 & 19.7 \\
\hline Lp4-m2 & 12.2 & 12.7 & 11.8 & 12.3 & 12.4 & & 11.9 \\
\hline Height before $\mathrm{ml}$ & 6.5 & 6.2 & 4.8 & 5.4 & 6.0 & 6.0 & 6.0 \\
\hline $\begin{array}{l}\text { Height of the } \\
\text { vertical ramus }\end{array}$ & 15.7 & 15.6 & 14.4 & 15.5 & & 15.3 & \\
\hline \multicolumn{8}{|c|}{ Teeth } \\
\hline Lc1 & & & & - & & & \\
\hline $\mathrm{Wc1}$ & & & & 2.6 & & & \\
\hline Lp2 & 2.2 & & 2.3 & 2.3 & & 2.1 & \\
\hline Wp2 & 1.5 & & 1.5 & 1.6 & & 1.3 & \\
\hline Lp3 & & & 2.9 & 2.6 & 2.8 & 3.0 & \\
\hline Wp3 & & & 1.7 & 1.8 & 1.7 & 1.7 & \\
\hline Lp4 & 3.8 & & 3.2 & 3.4 & 3.6 & & \\
\hline Wp4 & 2.2 & & 1.9 & 1.8 & 19.3 & & \\
\hline Lm1 & 7.3 & 7.2 & 6.8 & 7.6 & 7.4 & 7.2 & 7.3 \\
\hline Ltrdm1 & 5.3 & 5.3 & 5.2 & 5.6 & 5.4 & 4.9 & 5.2 \\
\hline Wm1 & 2.6 & 2.6 & 2.7 & - & 2.7 & 2.7 & 2.7 \\
\hline Lm2 & & 1.7 & & & & & \\
\hline $\mathrm{Wm} 2$ & & 1.3 & & & & & \\
\hline
\end{tabular}

Table 8. Measurements (mm) of female mandibles of Mustela eversmanii from the Russian Far East.

\begin{tabular}{|c|c|c|c|c|c|c|}
\hline \multirow{3}{*}{ Measurements } & \multicolumn{5}{|c|}{ Late Pleistocene } & \multirow{3}{*}{$\begin{array}{c}\text { M. e. amurensis, } \\
\text { recent } \\
\text { Amur Region } \\
\text { ZMMU S- } \\
82907 \text { 9 }\end{array}$} \\
\hline & \multicolumn{5}{|c|}{ Bliznets Cave } & \\
\hline & $\begin{array}{c}\text { ZIN } \\
37928-30\end{array}$ & $\begin{array}{c}\text { ZIN } \\
37928-33\end{array}$ & $\begin{array}{c}\text { ZIN } \\
37928-34\end{array}$ & $\begin{array}{c}\text { ZIN } \\
37928-39\end{array}$ & $\begin{array}{c}\text { ZIN } \\
37928-45\end{array}$ & \\
\hline Total length & & 31.4 & & & & 33.2 \\
\hline Lc1-m2 & 20.4 & 18.8 & & 19.8 & & 21.1 \\
\hline Lp4-m2 & 12.5 & 11.4 & 11.8 & 12.1 & 11.4 & 12.3 \\
\hline Height before $\mathrm{m} 1$ & 6.3 & 5.2 & 6.0 & 5.8 & 5.7 & 6.9 \\
\hline $\begin{array}{l}\text { Height of the } \\
\text { vertical ramus }\end{array}$ & 16.0 & & 15.8 & & 15.4 & 16.4 \\
\hline \multicolumn{7}{|c|}{ Teeth } \\
\hline Lc1 & 4.4 & & & 4.0 & & 4.0 \\
\hline $\mathrm{Wc1}$ & 2.9 & & & 2.7 & & 2.8 \\
\hline Lp2 & & & & 2.3 & 2.2 & 2.1 \\
\hline Wp2 & & & & 1.5 & 1.4 & 1.4 \\
\hline Lp3 & & 2.6 & & 2.9 & & 3.0 \\
\hline Wp3 & & 1.7 & & 2.0 & & 1.9 \\
\hline Lp4 & 3.8 & 3.5 & 3.9 & 3.1 & 3.6 & 3.4 \\
\hline Wp4 & 2.1 & 1.9 & 1.8 & 2.0 & 2.3 & 2.3 \\
\hline Lm1 & 7.7 & 6.8 & 7.1 & 7.1 & 7.1 & 7.3 \\
\hline Ltrdm1 & 5.7 & 5.0 & 5.3 & 5.3 & 5.3 & 5.6 \\
\hline Wm1 & 2.8 & 2.5 & 2.7 & 2.9 & 2.7 & 2.9 \\
\hline Lm2 & & 1.7 & & & & 1.6 \\
\hline $\mathrm{Wm} 2$ & & 1.5 & & & & 1.7 \\
\hline
\end{tabular}


Table 9. Measurements (mm) of mandibles of Mustela nivalis from the Russian Far East.

\begin{tabular}{|c|c|c|c|c|c|c|}
\hline \multirow{3}{*}{ Measurements } & \multicolumn{4}{|c|}{ Late Pleistocene } & Holocene & \multirow{2}{*}{$\begin{array}{c}\text { M. n. nivalis, } \\
\text { recent } \\
\text { Manchuria, } \\
\text { China }\end{array}$} \\
\hline & \multicolumn{5}{|c|}{ Bliznets Cave } & \\
\hline & $\begin{array}{c}\mathrm{ZIN} \\
37927-1 \\
\end{array}$ & $\begin{array}{c}\mathrm{ZIN} \\
37927-3 \\
\end{array}$ & $\begin{array}{c}\mathrm{ZIN} \\
37929-1 \\
\end{array}$ & $\begin{array}{c}\text { ZIN } \\
37929-5\end{array}$ & $\begin{array}{c}\text { ZIN } \\
37929-3\end{array}$ & ZIN 34615 ד \\
\hline Total length & & & 16.4 & & 15.9 & 15.9 \\
\hline Lc1-m2 & 9.2 & 10.1 & 9.8 & 10.0 & 9.7 & 9.8 \\
\hline Lp4-m2 & 5.4 & 5.9 & 6.1 & & 6.4 & 5.8 \\
\hline Height before $\mathrm{m} 1$ & 2.3 & 2.4 & 2.5 & 2.6 & 2.4 & 2.4 \\
\hline $\begin{array}{l}\text { Height of the vertical } \\
\text { ramus }\end{array}$ & & 7.8 & 7.7 & & & 7.8 \\
\hline \multicolumn{7}{|c|}{ Teeth } \\
\hline Lc1 & & & & 1.7 & & 1.9 \\
\hline Wc1 & & & & 1.1 & & 1.3 \\
\hline Lp3 & & & 1.1 & & & 1.2 \\
\hline $\mathrm{Wp} 3$ & & & 0.7 & & & 0.8 \\
\hline Lp4 & & & & 1.5 & & 1.8 \\
\hline Wp4 & & & & 0.8 & & 1.0 \\
\hline Lm1 & 3.2 & 3.5 & 3.8 & 3.3 & 3.7 & 3.7 \\
\hline Ltrdm1 & 2.4 & 2.5 & 2.7 & 2.6 & 2.7 & 2.7 \\
\hline $\mathrm{Wm} 1$ & 1.1 & 1.4 & 1.3 & 1.1 & 1.3 & 1.3 \\
\hline
\end{tabular}

